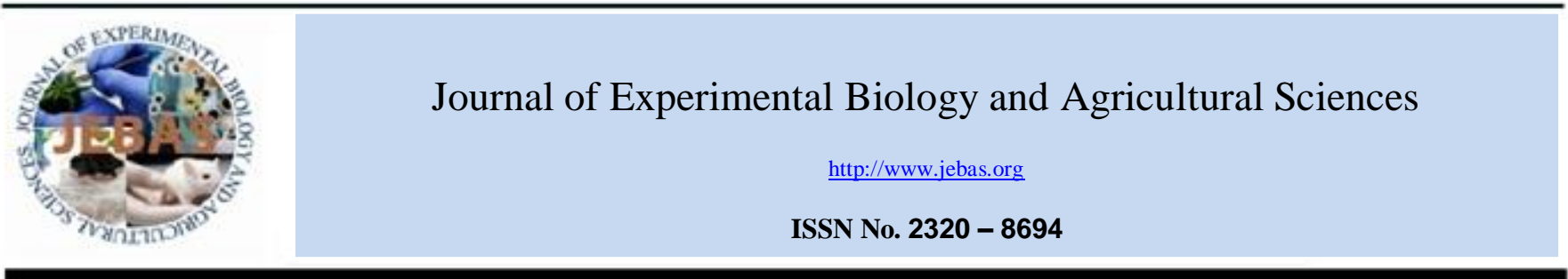

\title{
CRUDE GLYCEROL: BY-PRODUCT OF BIODIESEL INDUSTRIES AS AN ALTERNATIVE ENERGY SOURCE FOR LIVESTOCK FEEDING
}

\author{
Lokesha $E^{1 *}$, Marappan Gopi ${ }^{2}$, Ramasamy Dhinesh Kumar ${ }^{3}$, Brijesh Patel ${ }^{1}$, Banakar PS $^{3}$, \\ Revanasiddu Deginal ${ }^{3}$, Pruthviraj DR ${ }^{1}$, Bhanuprakash $\mathrm{V}^{1}$, Mahesh $\mathrm{MS}^{4}$
}

\footnotetext{
${ }^{1} \mathrm{Ph} . \mathrm{D}$ Scholar, ICAR-Indian Veterinary Research Institute, Izatnagar, India

${ }^{2}$ Scientist, ICAR-Central Avian Research Institute, Izatnagar, India

${ }^{3}$ Ph.D Scholar, ICAR-National Dairy Research Institute, Karnal, India

${ }^{4}$ Product Manager, Provimi Animal Nutrition India Pvt. Ltd., Bengaluru.
}

Received - October 15, 2017; Revision - November 30, 2017; Accepted - December 16, 2017

Available Online - December 27, 2017

DOI: http://dx.doi.org/10.18006/2017.5(6).755.766

KEYWORDS
Biodiesel
Crude glycerol
Glycogenic
Green house gases
Livestock feeding

\begin{abstract}
Increased concern on greenhouse gas emission, concomitant global warming and decreasing fossil fuels have created the necessity to find an alternative source of energy for the transportation vehicles. Biodiesels is an alternative renewable fuel source, which releases less carbon dioxide, carbon monoxide, sulfur and nitrogen oxides upon combustion. These environmental friendly features of biodiesel make it a potential alternative to the conventional one. Biodiesel can be extracted from the edible or non-edible source of triglycerides. During this extraction process, crude glycerol (CG) is obtained at the rate of $10 \%$ as a byproduct of trans-esterification reaction. Chemically, CG so obtained is composed of catalysts, salts and fatty acids. Purification of CG to $>95 \%$ involves the cost ( $0.28 \mathrm{USD} / \mathrm{L}$ production) and time consuming process. Hence, economical management of CG is the need of hour, one such alternative way is its entry in animal food chain as an energy source. Basically, glycerol is a glycogenic intermediate product of fat digestion converted to glucose by the action of key enzyme glycerol kinase. The CG undergo glycolysis and TCA cycle to liberate ATP. The digestible and metabolizable energy content of CG are comparable with the commonly used cereal grains in livestock feeding. Thus, CG acts as a bridging gap between the biodiesel industry and livestock production. Studies have showed that CG
\end{abstract}

* Corresponding author

E-mail: lokeshvet930@rediffmail.com (Lokesha E)

Peer review under responsibility of Journal of Experimental Biology and Agricultural Sciences.

Production and Hosting by Horizon Publisher India [HPI] (http://www.horizonpublisherindia.in/).

All rights reserved.
All the article published by Journal of Experimental Biology and Agricultural Sciences is licensed under a Creative Commons Attribution-NonCommercial 4.0 International License Based on a work at www.jebas.org.

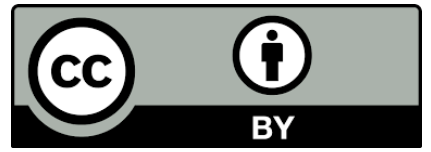


can be used as an energy source as a replacement of cereals in pig, poultry, goat, feedlot cattle and dairy cows. This review provides an overview of utilization of $\mathrm{CG}$ and its effect on production performance of different livestock species.

\section{Introduction}

Green house gases (GHG) emission is continued to be a major concern over many centuries due to increase in earth atmospheric temperature by $0.8^{\circ} \mathrm{C}$ since 1880 (NASA, 2015). Transportation sector contributes $14 \%$ to total global GHG emission (IPCC, 2014). To combat the negative impact of GHG emission from transportation fuels, developing countries shifting towards the alternative source of energy such as biodiesel production. Biodiesel is renewable, nontoxic, biodegradable, aromatic and free from sulfur gases. Additionaly, its better lubricity improves the engine performance and lifespan (Al-Zuhair, 2007). These environmental friendly features made feasible to utilize biodiesel as an alternative to diesel in vehicles, thereby decreasing dependency on rapidly depleting fossil fuel resources. Biodiesel can be obtained from sources of triglycerides such as vegetable oil or animal fat by a process called trans-esterification in the presence of catalyst methanol or ethanol (Hu et al., 2012). During the extraction process of biodiesel, glycerol is obtained at the rate of $10 \%$ as a byproduct of trans-esterification reaction (Posada et al., 2012). Glycerol so obtained is called crude glycerol (CG) since it is mixed with the impurities like catalysts, salts and fatty acids. Use of vegetable oils as a source of triglycerides for biodiesel production competes with the human food chain. Keeping this in mind many research studies took place to use nonedible oilseeds, waste oils, byproducts of the slaughter house, algae etc., as an alternative source of triglycerides. Various improvements in the method of extraction process by using different types of catalysts, enzymes, alcohols, different temperature and pressure combination has led to decrease in the cost involved and improving the efficiency of biodiesel extraction (Refaat, 2010) (Figure 1). Currently, the biodiesel production in

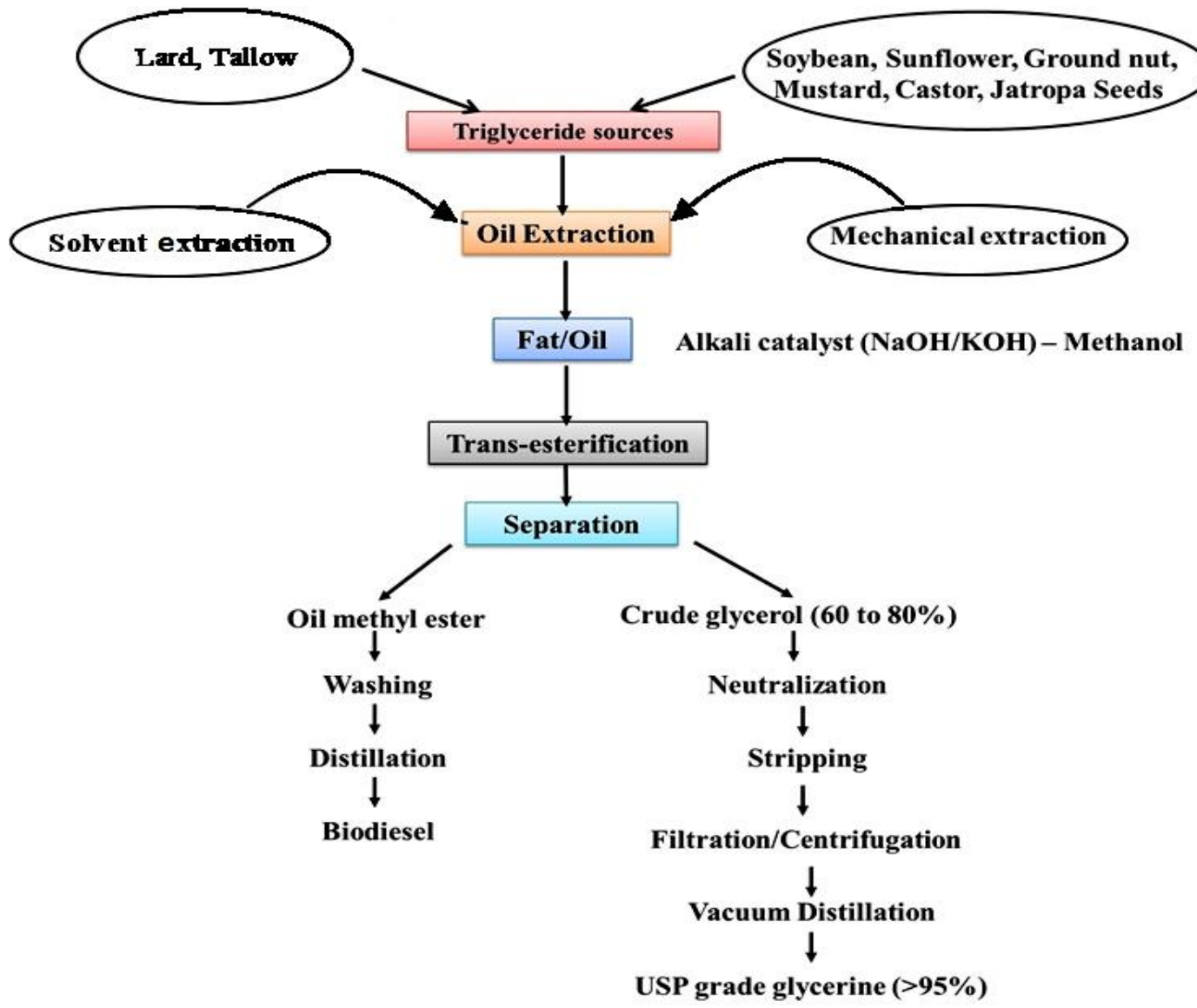

Figure 1 Steps involved in biodisel extraction process (Shuit et al.,2010).

Journal of Experimental Biology and Agriculture Science

http://www.jebas.org 
the world is around 29.7 billion liters which could create a huge amount of CG availability (REN21, 2015). Purified CG (>95\%) are being used in the food, cosmetic and pharma industries. Purification of CG to $99 \%$ purity is a costlier affair, as it requires $0.28 \mathrm{US} \$ / \mathrm{L}$ of production. The presence of impurities in CG affects the operational cost of the industrial process and also not feasible under small or medium scale biodiesel plants (Posada et al., 2012).

CG has a high Chemical Oxygen Demand (COD). Disposal as such in the open environment may pose environmental pollution. An alternative to purification and disposal, CG can also be used in the synthesis of many other commercial products by chemical (syn- gas, acrolein, 1, 2- propanediol) and bio-chemical (ethanol, 1, 3-propanediol, D- lactic acid, succinic acid, propionic acid and poly-3-hydroxybutyrate) processes. However, these are time consuming and involve use of chemicals, microorganisms and sophisticated facilities (Posada et al., 2012). Various researches are being carried out for an economical and environmentally friendly utilization of the by-product throughout the world. One such alternate utility will be an entry in the animal food chain as an energy source. The gross energy (GE, $3.3-6.7 \mathrm{Mcal} / \mathrm{kg}$ ) and metabolizable energy (ME, $2.9-4.8 \mathrm{Mcal} / \mathrm{kg}$ ) values of $\mathrm{CG}$ are comparable with maize grains, the most commonly used ingredient in concentrate feed preparation (Jung \& Batal, 2011; Benedetiet al., 2015). Moreover, glycerol being the intermediate product of glycolysis serves as an energy source which can be utilized in ketosis. In this review, an attempt has been made to reveal the nutritional significance of CG, its composition, level of inclusion in different kind of animals, and effect on production are discussed in different headings.

\section{Composition of CG}

After biodiesel extraction, CG left over consists of impurities like methanol, soap, fatty acids, esters, and catalysts. The color of CG depends on the pigmentation of the source used for biodiesel extraction and varies from light brown to dark brown (Hansen et al., 2009). The density of CG ranged from 1.01 to $1.20 \mathrm{~g} / \mathrm{cm}^{3}$ and $\mathrm{pH}$ ranges from 6.4 to 10 and that of pure glycerol is $1.31 \mathrm{~g} / \mathrm{cm}^{3}$ and 6.4 respectively (Hu et al., 2012). Chemical composition of CG obtained from different sources is given in table 1. Source of triglyceride, the catalyst used and the process of extraction defines the composition of CG (Yang et al., 2012). CG derived from six different sources of triglycerides (mustard, rapeseed, canola, crambe, soybean and waste cooking oil) contained 0.06 to $0.44 \%$,

Table 1 Composition of crude glycerol extracted from different sources

\begin{tabular}{|c|c|c|c|c|c|c|c|}
\hline Source of triglyceride & Glycerol & Methanol & Moisture & Crude protein & Ash & Crude fat & Reference \\
\hline Waste vegetable oil & 63.42 & 4.38 & 13.93 & 0.03 & 7.41 & 9.57 & Chanjula et al., (2016b) \\
\hline Soybean oil & 86.95 & 0.028 & 9.22 & 0.41 & 3.19 & 5.33 & Lammers et al., (2008a) \\
\hline Vegetable oil & 87.42 & 0.05 & 7.98 & ----- & 5.87 & ----- & Orengo et al., (2014) \\
\hline Palm oil & 88.91 & 0.52 & 5.6 & 0.01 & 3.51 & --- & Chanjula et al., (2016b) \\
\hline Rapeseed oil & 80.00 & 0.50 & -- & --- & 8.00 & --- & Barton et al., (2013) \\
\hline Soybean oil & 80.34 & ----- & 12.02 & --- & 5.03 & 1.59 & Lage et al., (2014a) \\
\hline Soybean oil & 80.30 & 0.40 & 12.40 & --- & ---- & --- & Shin et al., (2012) \\
\hline Pork fat & 74.74 & 0.0 & 10.32 & 0.88 & ----- & ---- & Silveira et al., (2015) \\
\hline $\begin{array}{l}\text { Castor, soybean, sunflower, } \\
\text { cotton seed oil. }\end{array}$ & 36.2 & 8.7 & 6.2 & 0.4 & 2.00 & ----- & Lage et al., (2014b) \\
\hline Soybean, sunflower & 83 & 0.01 & 11 & ----- & 6.00 & ----- & Carvalho et al., (2015) \\
\hline Source not available* & 82.6 & 0.4 & 7.1 & $\ldots$ & 9.30 & 0.6 & Kass et al., (2013) \\
\hline Soybean & 80.34 & 0.003 & 12.02 & 1.15 & 5.72 & 1.81 & San et al., (2015) \\
\hline Source not available* & 86.6 & 0.003 & 7.5 & ----- & 5.88 & ----- & Egea et al., (2016) \\
\hline Source not available* & 86.6 & 0.028 & 9.22 & 0.41 & 3.19 & 0.12 & Lammers et al., (2008b) \\
\hline Source not available* & 84.37 & 0.01 & 10.72 & 0.65 & 3.21 & 0.33 & Kim et al., (2013) \\
\hline From 11 different sources & 72.4 & 4.12 & 5.5 & ----- & 5.20 & ----- & Hansen et al., (2009) \\
\hline
\end{tabular}

* Obtained from biodiesel plant but source not available.

Journal of Experimental Biology and Agriculture Science http://www.jebas.org 
1 to $13 \%$ and 75 to $83 \%$ as protein, fat and carbohydrate, respectively. Whereas, the fat and carbohydrate in waste cooking oil was about 60 and 27\%, respectively (Thompson \& He, 2006). Almost $90 \%$ of ash in CG consists of sodium chloride derived from the catalyst used during extraction process (Orengo et al., 2014; Chanjula et al., 2016b). Other minerals such as Ca, P, K, $\mathrm{Cu}, \mathrm{Zn}, \mathrm{Mg}$, and $\mathrm{Mn}$ are present in negligible amount have lesser importance in feeding (Jung \& Batal, 2011; Shin et al., 2012).

Among the different constituents of the CG, methanol is more important due to its toxic effect on central nervous system and causes blindness by converting into toxic metabolites formaldehyde and formic acid (Dorman et al., 1993). However,

till today no such adverse effects had been reported in any species of animals fed with the CG. The lower level of lipid to water partition coefficient of methanol shows that microorganisms having a better tolerance to methanol than the ethanol (Patterson \& Ricke, 2015) and it is advisable to use methanol instead of ethanol during biodiesel extraction process intended to use CG in animal feeding. Methanol concentration in the CG depends on the manufacturing process and stock feed. European Food Safety Authority (EFSA, 2010) limited amount of methanol in CG to $0.5 \%$ in the vegetable origin feedstock whereas, FDA (2010) allowed maximum up to $150 \mathrm{ppm}$ of methanol in the final animal feed. However, Lage et al. (2014b) demonstrated no deleterious effects even at $8.7 \%$ of methanol in feed lot lambs. It has been seen that the residual methanol will evaporate during feed processing and storage due to its volatile nature. Silveira et al. (2015) in his pig experiment used CG derived from pork fat which was liquefied at $65.5^{\circ} \mathrm{C}$ found $0.0 \%$ of methanol indicating evaporation at that temperature. In addition to methanol, sodium is considered as next contaminant of concern. As maximum sodium content in CG should be around 1.07 to $1.2 \%$, it may reach up to $1.4 \%$ (EFSA, 2010). Excess sodium is not a problem in ruminants until sufficient water is available for drinking; accordingly NRC (2001) has allowed maximum sodium $1.6 \%$ on the dry basis in the diet of lactating cattle without any negative impact on rumen fermentation and health status.

\section{Scope for feeding of CG in animals}

Limited availability of fossil fuels and increased global warming in recent years made biofuel a viable source of energy with low carbon emission, renewable and economical to use in transportation fuels. In 2014, global biofuel production reached around 123.7 billion liters of which 94 billion liters were ethanol and 29.7 billion liters were biodiesel (REN21, 2015). United States, Brazil, Germany, China and Argentina are the top countries in biofuel production. According to OECD/FAO (2015) prediction, expected world biodiesel production in 2024 will be around 35 billion liters. India's share in crude oil production is about 1 percent of global crude oil production, whereas consumption amounts to 3.1 percent of global consumption (Energy Statistics Report, 2003). Currently, India has 20 large biodiesel plants producing around 135 million liters of biodiesel and 2,219 million liters of bioethanol per year (USDA, 2015). National Biofuel Policy of India (2015) decided to blend 20\% of bioethanol and biodiesel with petrol and diesel respectively by the end of $12^{\text {th }}$ five year plan i.e. 2017 to decrease GHG emission, climate change mitigation for environmentally sustainable development, apart from other advantages like creating new employment opportunities. In order to achieve the target of $20 \%$ blending national biofuel policy set a target of dedicating 11.2 to 13.4 million hectares (Mha) of land to Jatropha cultivation by the end of its $11^{\text {th }}$ Five-Year Plan. However, it was a failure due to unawareness of farmers regarding agronomic practices of Jatropha cultivation, lack of field validation and standardization of oil yield and many other reasons which is behind the scope of this review (Singh et al., 2013; Edrisi et al., 2015). Several state governments along with the central government are providing incentives to farmers for planting Jatropha and other non-edible oilseeds. The expected increase in biodiesel production creates the excess availability of $\mathrm{CG}$ as a byproduct which can be utilized as an energy source for the livestock's which in turn reduces the dependence on the cereals and cereal by-products.

\section{Nutritive value of CG}

Chemically, glycerol is a sugar alcohol and highly soluble in water. Its sweetish taste increases the palatability of the diet (Groesbeck et al., 2008). Ghrelin a peptide hormone secreted from the stomach mucosa is considered as hunger hormone, increase in acyl ghrelin in pigs fed with CG in their diet indicated the tendency of increase in appetite (Orengo et al., 2014). Ingested glycerol absorbed by passive diffusion and acts as a readily available source of energy. Glycerol kinase is a key enzyme in the liver for initiation of glycerol utilization. It converts the glycerol to glycerol 3-phosphate, which in turn get converted to glucose by gluconeogenesis or oxidized to give energy by glycolysis or citric acid cycle (Figure 3). Viscous nature of CG reduces the dustiness of the feed in mash type of diet, but increasing it more than $8 \%$ of the diet in pig resulted in feeding difficulty due to the formation of an aggregate of feed to firm mass (Hansen et al., 2009) (Table 2). A similar finding was reported by Cerrate et al. (2006) in poultry birds increasing CG up to $10 \%$ affected the flow rate of feed in tube feeder and pellet quality. Whereas, the addition of CG prior to pelleting increased the pellet durability and feed mill production efficiency at $9 \%$ level in piglet diet preparation (Groesbeck et al., 2008). Lammer et al., (2008a) from his five experimental results, each consisting of different levels of CG in growing pig's diet concluded the average digestible energy (DE) 
Table 2 Different levels of inclusion of CG and methanol in animal diet without any adverse effects

\begin{tabular}{|c|c|c|c|c|c|c|}
\hline $\begin{array}{l}\text { Source of } \\
\text { Biodiesel }\end{array}$ & $\begin{array}{l}\begin{array}{c}\text { Purity } \\
\text { of } \\
\text { Glycerol } \\
\%\end{array} \\
\end{array}$ & $\begin{array}{c}\text { Methano } \\
\text { I }(\%)\end{array}$ & $\begin{array}{l}\text { Inclusion } \\
\text { level on } \\
\text { total DM } \\
\text { basis }\end{array}$ & Species & Research findings & Reference \\
\hline $\begin{array}{l}\text { Vegetable } \\
\text { oil (CGS) } \\
\text { Mixed oil } \\
\text { (animal fat } \\
\text { and soybean } \\
\text { oil, CGA) }\end{array}$ & $\begin{array}{l}55.95 \\
(\mathrm{CGS}) \\
\\
55.45 \\
(\mathrm{CGA})\end{array}$ & $\begin{array}{c}10.96 \\
(\mathrm{CGS}) \\
\\
5.05 \\
(\mathrm{CGA})\end{array}$ & $\begin{array}{c}4,8 \text { and } \\
12 \%\end{array}$ & Piglets & $\begin{array}{l}\text { 1. DE and ME values of CGS and CGA are } 5,070 \text { and } 4,556 \text {, } \\
5,143 \text { and } 4,488 \mathrm{kcal} / \mathrm{kg} \text { respectively. } \\
\text { 2. Source of CG had no significant effect on performance of the } \\
\text { animals. } \\
\text { 3. CG of both the types included up to } 12 \% \text { reduced the feed cost } \\
\text { by } 11 \% \text {. }\end{array}$ & $\begin{array}{l}\text { Carvalho et al., } \\
\text { (2012b) }\end{array}$ \\
\hline \multirow{2}{*}{ Anonymous } & 82.6 & 0.4 & $\begin{array}{c}1,2 \text { and } \\
3 \mathrm{~kg} / \text { head }\end{array}$ & Cows & $\begin{array}{l}\text { 1. Increased level of feed intake with increase in dose. } \\
\text { 2. No effect on milk yield, milk protein increased significantly in } \\
\text { all treatment group. } \\
\text { 3. Lower blood NEFA and higher blood urea. } \\
\text { 4. CG can be used to replace barley without any detrimental } \\
\text { effect on microbial fermentation and lactation performance. }\end{array}$ & Kass et al., (2012) \\
\hline & 88.8 & 0.75 & $\begin{array}{c}7.5 \text { and } \\
15 \%\end{array}$ & $\begin{array}{l}\text { Weaned } \\
\text { pigs }\end{array}$ & $\begin{array}{l}\text { 1. Caecal Clostridium spp. and Lactobacillus spp. were linearly } \\
\text { reduced by CG inclusion level. } \\
\text { 2. The glycerol kinase and relative mRNA expression in liver } \\
\text { increased linearly with increasing CG. } \\
\text { 3. CG up to } 15 \% \text { can be adopted easily by weaned piglets }\end{array}$ & $\begin{array}{l}\text { Papadomichelakis } \\
\text { et al., (2012) }\end{array}$ \\
\hline Rapeseed oil & 80 & $<0.5$ & $\begin{array}{c}5 \text { and } 10 \\
\%\end{array}$ & Bulls & $\begin{array}{l}\text { 1. No significant effect on growth performance, carcass and meat } \\
\text { quality traits. } \\
\text { 2. No effect on blood and rumen metabolites. } \\
\text { 3. CG can be used as a long-term substitution for barley meal up } \\
\text { to } 10 \% \text { in finishing bulls. }\end{array}$ & $\begin{array}{l}\text { Barton et al., } \\
\text { (2013) }\end{array}$ \\
\hline Anonymous & 84.37 & $<0.01$ & $5 \%$ & $\begin{array}{l}\text { Broiler } \\
\text { chicken }\end{array}$ & $\begin{array}{l}\text { 1. Apparent total tract digestibility and gross energy was more } \\
\text { than the basal diet. } \\
\text { 2. No effects of CG on intestinal transit time of birds and nutrient } \\
\text { utilization in diets. }\end{array}$ & Kim et al., (2013) \\
\hline $\begin{array}{l}\text { Vegetable } \\
\text { oil }\end{array}$ & 36.20 & 8.7 & $\begin{array}{c}3,6,9 \\
\text { and } 12 \%\end{array}$ & Lambs & $\begin{array}{l}\text { 1. Quadratic effect of level of CG was observed on final body } \\
\text { weight and carcass weight. } \\
\text { 2. Inclusion of CG tended to reduce the } \mathrm{Zn} \text { content in meat. } \\
\text { 3. No effect on performance and carcass traits of the animals, } \mathrm{CG} \\
\text { may be used in the diets of finishing lambs as a replacement to } \\
\text { concentrate }\end{array}$ & $\begin{array}{l}\text { Lage et al., } \\
\text { (2014b) }\end{array}$ \\
\hline Anonymous & 87.5 & 0.05 & 2 and $4 \%$ & $\begin{array}{l}\text { Young } \\
\text { bulls }\end{array}$ & $\begin{array}{l}\text { 1. No effect on daily feed intake, weight gain, feed conversion } \\
\text { efficiency and carcass characteristics. } \\
\text { 2. CG can be used to replace barley up to } 4 \% \text { without any adverse } \\
\text { effect on animal performance. }\end{array}$ & Egea et al., (2014) \\
\hline $\begin{array}{l}\text { Vegetable } \\
\text { oil }\end{array}$ & 87.42 & 0.05 & $10 \%$ & Pigs & $\begin{array}{l}\text { 1. Higher average daily gain and feed intake. } \\
\text { 2. Tendency of increase in acyl-ghrelin in CG fed group was } \\
\text { observed. } \\
\text { 3. CG can replace wheat up to } 10 \% \text { without any adverse effect. }\end{array}$ & $\begin{array}{l}\text { Orengo et al., } \\
\quad(2014)\end{array}$ \\
\hline \multirow[b]{2}{*}{ Anonymous } & 85 & $<0.5$ & $\begin{array}{c}9 \text { and } 18 \\
\%\end{array}$ & $\begin{array}{l}\text { Weanin } \\
\text { g pigs }\end{array}$ & $\begin{array}{l}\text { 1. No effect on nutrient digestibility and blood metabolites. } \\
\text { 2. At higher level of CG increased the excretion of glycerol in the } \\
\text { urine indicating saturation of metabolism. } \\
\text { 3. Cell structure and cytokine expression in the intestinal cell } \\
\text { could be affected with higher glycerin addition in piglet diet. }\end{array}$ & $\begin{array}{l}\text { Oliveira et al., } \\
\quad(2014)\end{array}$ \\
\hline & 73.5 & 1.52 & $\begin{array}{c}3,6,9 \\
\text { and } 12 \%\end{array}$ & Steer & $\begin{array}{l}\text { 1. Dry matter intake, nutrient digestibility and microbial protein } \\
\text { synthesis were not affected by CG. } \\
\text { 2. Intestinal and total digestibility of lipids improved by } \mathrm{CG} \\
\text { inclusion. } \\
\text { 3. CG can be used as a good alternative to ground corn up to } 12 \% \\
\text { of total DM. }\end{array}$ & $\begin{array}{l}\text { Serrano et al., } \\
\text { (2014) }\end{array}$ \\
\hline Soybean oil & 80.34 & --- & $10 \%$ & Bull & $\begin{array}{l}\text { 1. CG as a substitute for corn or soybean hull had no significant } \\
\text { effect on carcass or meat quality traits however insignificant } \\
\text { increase in monounsaturated fatty acids and CLA was noticed. }\end{array}$ & $\begin{array}{l}\text { Lage et al., } \\
\text { (2014a) }\end{array}$ \\
\hline $\begin{array}{l}\text { Soya bean } \\
\text { oil }\end{array}$ & 70 & 0.018 & $\begin{array}{l}1.75,3.5 \\
5.25 \text { and } \\
7 \%\end{array}$ & $\begin{array}{l}\text { Broiler } \\
\text { birds }\end{array}$ & $\begin{array}{l}\text { 1. More weight gain, better feed conversion and highest breast } \\
\text { yield was observed at } 3.55 \% \text { inclusion level. }\end{array}$ & $\begin{array}{l}\text { Bernardino et al., } \\
\text { (2015) }\end{array}$ \\
\hline
\end{tabular}

Journal of Experimental Biology and Agriculture Science http://www.jebas.org 


\begin{tabular}{|c|c|c|c|c|c|c|}
\hline $\begin{array}{l}\text { Source of } \\
\text { Biodiesel }\end{array}$ & $\begin{array}{c}\begin{array}{c}\text { Purity } \\
\text { of } \\
\text { Glycerol } \\
\%\end{array} \\
\end{array}$ & $\begin{array}{c}\text { Methanol } \\
(\%)\end{array}$ & $\begin{array}{l}\text { Inclusion } \\
\text { level on } \\
\text { total DM } \\
\text { basis }\end{array}$ & Species & Research findings & Reference \\
\hline $\begin{array}{l}\text { Soybean } \\
\text { and } \\
\text { sunflower }\end{array}$ & 83 & 0.01 & $\begin{array}{c}7.5,15 \text {, } \\
22.5 \text { and } \\
30 \%\end{array}$ & Lambs & $\begin{array}{l}\text { 1. At } 30 \% \text { addition reduced carcass weight and yield. } \\
\text { 2. Odd-chain fatty acids, oleic, palmitoleic, total unsaturated, } \\
\text { and monounsaturated fatty acids were increased. } \\
\text { 3. Tendency of increasing CLA in glycerin-fed lambs }(\mathrm{P}=0.06) \\
\text { was observed. } \\
\text { 4. CG decreased stearic, palmitic trans-vaccenic, total saturated } \\
\text { fatty acids, and atherogenicity index. }\end{array}$ & $\begin{array}{c}\text { Carvalho et al., } \\
\text { (2015) }\end{array}$ \\
\hline Soybean oil & 87.98 & 0.003 & $\begin{array}{c}7,14,21 \\
\text { and } 28 \%\end{array}$ & Bulls & $\begin{array}{l}\text { 1. No change in carcass characteristics and meat quality. } \\
\text { 2. pH decreased linearly, and margaric acid (17:0) increased in } \\
\text { the longissimus muscle with the addition of glycerin in the } \\
\text { diet. } \\
\text { 3. CG up to } 28 \% \text { can be included in the diet without any } \\
\text { adverse effect. }\end{array}$ & San et al., (2015) \\
\hline
\end{tabular}

and ME value of CG 3,344 \pm 8 and 3,207 $\pm 10 \mathrm{kcal} / \mathrm{kg}$, respectively. Average ME content of CG was reported to be 3,434 $\mathrm{kcal} / \mathrm{kg}$ in broiler chickens (Dozier et al., 2008).

\section{CG as in livestock feed}

\subsection{Non-ruminants}

Use of glycerol as an energy supplement in animal feeding is not a new concept. Increased availability of CG as a byproduct from biodiesel industry paves the way for its use in formulating leastcost animal feed. Pure glycerol as a source of carbohydrate in transition animals to cure ketosis was reported by Fisher et al. (1971). However, the concept of glycerol utilization in pig feeding was started in 1990's (Kijora \& Kupsch, 1996). Animals require time to adjust for the introduction of CG in the basic diet, this adjustment period is different for different kind of animals. In weaned pigs, supplementation in initial 35days decreased expression of glycerol kinase indicating decreased utilization followed by increased expression (Papadomichelakis et al., 2012).

Glycerol being the intermediate product of glycolysis acts as an energy source. Research studies have been conducted on replacement of energy sources such as cereal grains in the diet of the animals by isocaloric CG proved, $\mathrm{CG}$ as a better alternative (Orengo et al., 2014; Chanjula et al., 2016a). The inclusion of CG at various levels found safe with no adverse effects on feed utilization and body weight. Inclusion of CG (10\%) in growing pig diet had no significant effect on feed intake, feed conversion ratio, carcass traits and average daily gain (Hansen et al., 2009; Carvalho et al., 2012b; Egea et al., 2016). Replacing isocaloric cereals with $\mathrm{CG}$ at $12 \%$ level in piglet diet reduced feed cost by $11 \%$ (Carvalho et al., 2012b). In contrary, inclusion level higher than $10 \%$ in porcine diet resulted in excretion of glycerol without metabolism in urine due to saturation of enzymes in the liver
(Lammers et al., 2008a). Nursery piglet diet with added glycerol did not affect the intake, digestibility, growth and development of GIT (Oliveira et al., 2014). No effect of CG on blood insulin or glucose concentration was observed in many studies (Lammers et al., 2008a; Hansen et al., 2009; Orengo et al., 2014).

Inclusion level of 2.5 and 5\% was acceptable without any adverse effect on feed intake, feed conversion efficiency, growth rate and digestibility in broilers (Cerrate et al., 2006). Papadomichelakis et al. (2015) concluded that feeding CG at 7\% level improved the feed efficiency in broilers but did not affect the growth rate. Further increase in $\mathrm{CG}$ to 10 to $21 \%$ affected the bird's performance, feed intake and increased the water intake which affected litter quality (Cerrate et al., 2006; Papadomichelakis et al., 2015). Loose litter quality may result in coccidiosis and mortality. Egg production, egg weight were not affected at 5, 10 and $15 \%$ inclusion level of CG in layers (Lammers et al., 2008b) (Table 2).

\subsection{Effect of CG feeding on rumen fermentation and digestibility of CG}

Glycerol utilization in ruminants is different from that of mono gastric animals. However, functionality is due to the glycogenic property only. Glycerol after ingestion 50 to $80 \%$ disappears from the rumen within $4 \mathrm{~h}$ of feeding (Donkin, 2008). Glycerol which escapes from the rumen fermentation gets converted to glucose in the liver. It enters the gluconeogenesis pathway at the triose phosphate level and is not dependent on the rate-limiting enzymes pyruvate carboxylase and phosphoenolpyruvate carboxykinase for its conversion (Leng, 1970). A portion of glycerol subjected to microbial fermentation increases the propionate concentration and decreases the acetate to propionate ratio (Benedeti et al., 2015). The proportion of increased propionate and decreased acetate concentration decides the total volatile fatty acids concentration 
(TVFA). The increase in TVFA concentration was observed by Benedeti et al. (2015) and Lokesha et al., (2017), whereas, Chanjula et al. (2014) reported no change in the TVFA in spite of increased propionate production. Some of the researchers have also reported increased butyric acid and short chain fatty acids like valeric acid and isovaleric acid concentrations (Abo El-Nor et al., 2010; Shin et al., 2012) by CG fermentation (Table 2; Figure 2).

Megasphaera elsdenii and Selenomonas ruminantium are the two main glycerol utilizing bacteria found in the rumen (Krehbiel, 2008). Butyric acid is the main end product of Megasphaera elsdenii, which helps in maintaining the health of rumen epithelium, whereas, Selenomonas ruminantium ferments glycerin to propionate (Van et al., 2015). The addition of starch-rich readily available energy sources (grains, molasses) causes the decreased rumen $\mathrm{pH}$ due to lactic acid accumulation. Glycerol as a source of carbohydrate replaced with corn starch at 10 and $20 \%$ level had no significant effect on rumen $\mathrm{pH}$ and $\mathrm{NH}_{3}-\mathrm{N}$ level (Abo El-Nor et al., 2010; Long et al., 2015). The tendency to decrease $\mathrm{pH}$ and $\mathrm{NH}_{3}-\mathrm{N}$ was observed at $6 \%$ of $\mathrm{CG}$ feeding in goats and steers at $300 \mathrm{~g}$ per day (Wang et al., 2009; Chanjula et al., 2016b). Decreased pH may be due to the accumulation of lactic acid in the rumen and decreased $\mathrm{NH}_{3}-\mathrm{N}$ indicates the decreased proteolytic activity or increased utilization of nitrogen by the rumen microbes. Paggi et al. (1999) reported 20\% reduction in proteolytic activity with CG addition which could be explained with two mechanisms. First might be due to the structural property of glycerol having three

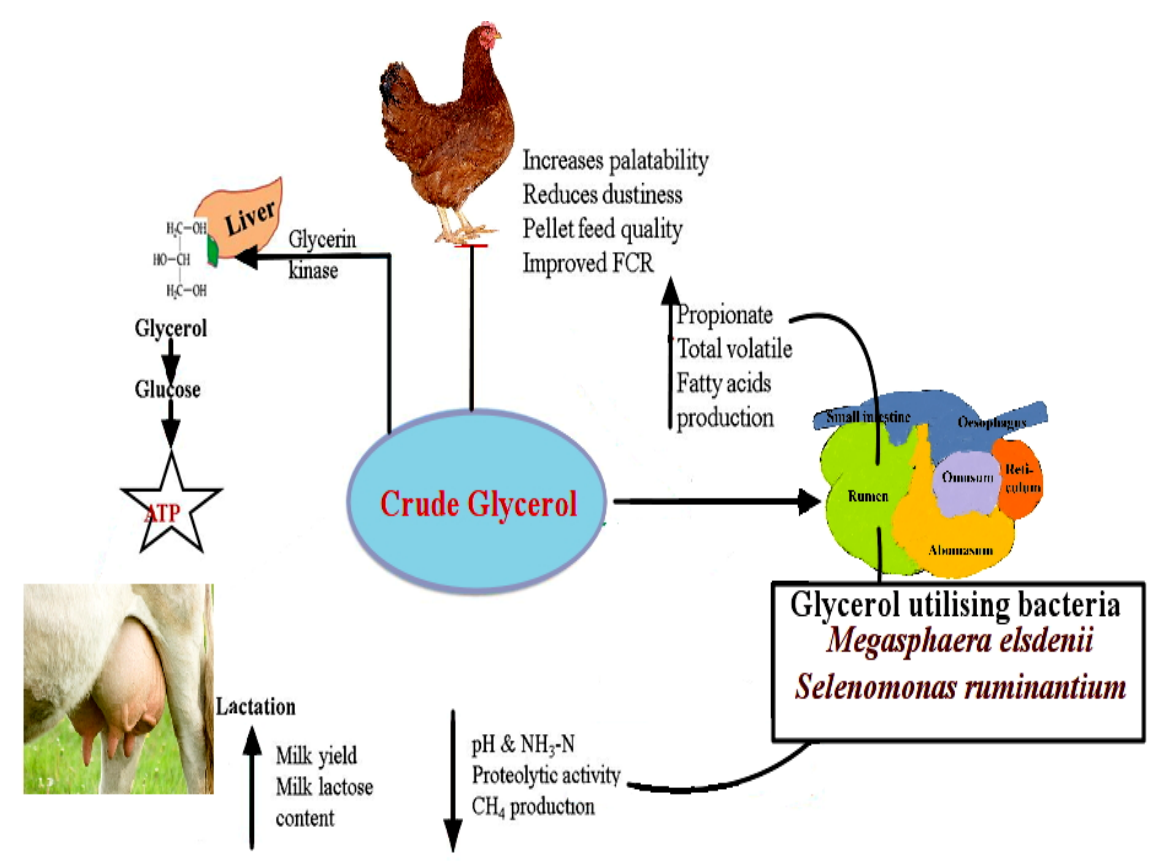

Figure 2 Effect of crude glycerol feeding in animals

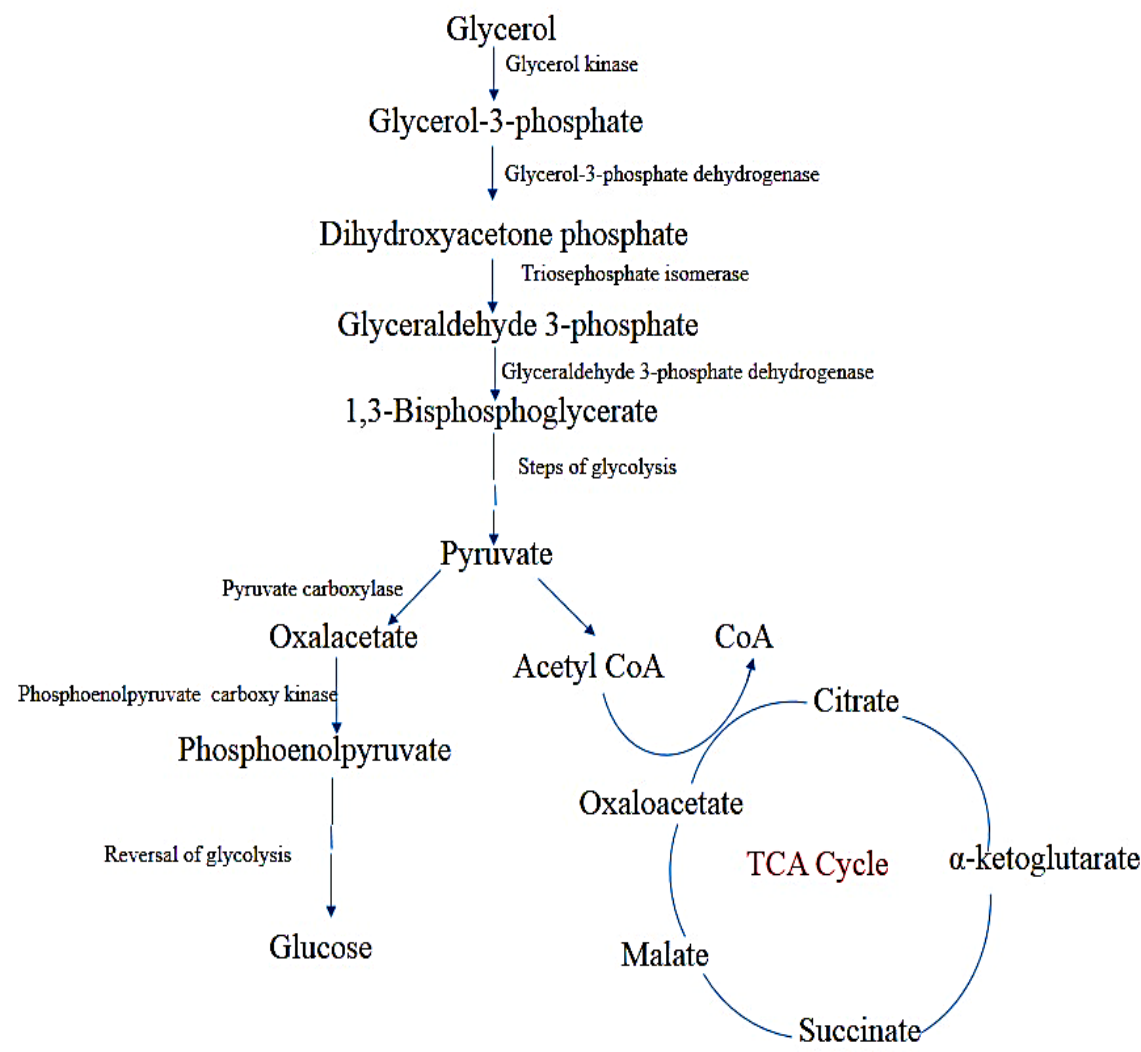

Figure 3 Metabolism of glycerol (McDonald, 2010) 
hydroxyl groups and lack of hydrophobic chain this would make the medium where glycerol is dissolved less suitable for the activity of the proteolytic enzymes. Another possible reason may be due to the presence of alcohol in the CG which will bind with protein and increases the resistance to proteolytic activity of rumen microbes (Patterson \& Ricke, 2015).

Crossbred goats fed with $\mathrm{CG}$ at $6 \%$ of DM significantly reduced dry matter intake (DMI), organic matter, crude protein, ether extract and fiber digestibility; however, no such adverse effect was noticed when fed at 2 and 4\% levels (Chanjula et al.,2016b). Similarly, Shin et al. (2012) in lactating cows replacing concentrate with $10 \% \mathrm{CG}$ also observed $30 \%$ reduction in neutral detergent fiber (NDF) digestibility. The negative effect of CG on fiber digestibility may be due to a preferential increase in propionate production at the cost of acetate or due to decreased fibrolytic bacteria Butyrivibrio fibrisolvens and Selenomonas ruminantium associated with the feed particles prevented adhesion and utilization of fiber (Abo El-Nor et al.,2010; Van et al., 2015).

The recent experimental result with increased CG also showed a significant decrease in fiber utilizing bacteria $R$. albus and $R$. flavefaciens and protozoa Entodinium and starch utilizing Isotricha, whereas, gram-negative fiber utilizing bacteria $F$. succinogenes showed resistant (San et al., 2016). However, several experimental results are available with no effect on fiber digestibility (Long et al., 2015; Benedeti et al., 2015; Lokesha et al., 2017) to CG addition (Table 2).

Wang et al. (2009) reported the dose-dependent effect of glycerol and suggested $200 \mathrm{~g} / \mathrm{d} / \mathrm{h}$ as an effective in stimulating the rumen fermentation activity and microbial protein production. Long-term feeding of CG at $10 \%$ level replaced at isoenergetic levels with barley grains in finishing bull's for 266 days had no adverse effect on blood metabolites, growth and carcass characteristics (Barton et al., 2013). Many short-terms and long-term trails showed effective utilization of CG as an alternative to cereal grains in finishing bulls, goats, sheep and dairy cows without any effect on nutrient intake, digestibility and blood metabolites (Avila-Stagno et al., 2013; Kass et al., 2013; Lage et al., 2014b). The reason for the adverse effect of CG on fiber digestibility is not clear and may depend on the total dietary constituents and CG composition.

\subsection{Effect of CG feeding on lactation}

Glycerol as an energy supplement to dairy cows during early lactation (DeFrain et al., 2004; Wang et al., 2009; Carvalho et al., 2012a) or mid-lactation (Donkin, 2008) has been demonstrated. Dairy cows fed with food grade glycerol (purity 99.8\%) showed positive energy balance by increased blood glucose and decreased blood NEFA, BHBA concentrations. However, the milk yield and its composition was not altered (Wang et al., 2009). In contrary, tendency of increasing milk yield and milk protein content was reported with high purity glycerol $(99.5 \%)$ than low purity glycerol (88.1\%) (Omazic et al., 2013). Kass et al., (2013) observed that oral drenching of CG $(500 \mathrm{ml} / \mathrm{d})$ in early lactating cows increases milk yield and milk lactose content than the control group. Donkin (2008) in dairy cows diet replaced 5, 10 and $15 \%$ corn with pure glycerol for 56 days of the experimental period, observed no change in milk yield and composition but a linear increase in blood glucose indicated the positive energy balance. Carvalho et al. (2012a) did not observe any change in milk production and composition in transition dairy cows fed glycerol 28 days before expected date of caving to 56 days postpartum at $11.5 \%$ and $10.8 \%$ of DM respectively in pre and post-partum animals.

\subsection{Effect of CG on Ruminal Methanogenesis}

Increased propionate in conjugation with decreased acetate concentration, in turn, decreases the availability of $\mathrm{H}_{2}$ for methane production (Van et al., 2015; Chanjula et al., 2016b). However, few studies, in vitro (Avila et al., 2011) and in vivo (Avila-Stagno et al., 2013) revealed an increase in propionate production and did not alter the methane production with CG feeding. In contrary, increased methane production with the linear increase in $\mathrm{CG}$ concentration in rumen simulation techniques was reported by Avila-Stagno et al. (2014). The author further predicted two possible explanation for increased methane production as, i. proportionate increase in butyrate resulted in release of reducing equivalents which increased methane production; ii. conversion of glycerol to methane precursors such as formate or ethanol. Patterson \& Hespell (1979) reported that methane production may be due to Methanosarcina, methanogens which is capable of utilizing the methanol as a source for methane production. However, no experimental results are available to confirm the hypothesis of alteration in the methanogenic archae population in the rumen. Paschoaloto et al. (2016) carried out successive in vitro studies with different CG levels with varying concentrate: roughage diets. The authors concluded that production of methane does not depend on the CG inclusion level rather it depends on NDF content of the substrate.

\subsection{Effect of feeding of CG on Carcass traits}

Most of the research studies conducted on broilers (Min et al., 2008), pigs (Hansen et al., 2009), steers (Francozo et al., 2013; Eiras et al., 2014) and goats (Lage et al., 2014b; Chanjula et al., 2014) had no significant impact on the carcass traits. It may be due to the fact that CG is having similar metabolism as that of the replaced cereals. However, few researchers such as Cerrate et al. (2006) reported a significant increase in breast yield in the dressed carcass of broiler at 2.5 and $5 \%$ level of CG compared to control group. Steers fed with 2 to $12 \%$ of CG (Egea et al., 2014) had 
higher meat arachidonic and linolenic acid content. The authors pointed out that decreased bio-hydrogenation in the rumen might be the reason behind it. Decreased fat digestion in the rumen fed with CG (Edwards et al., 2012) expected to decrease the biohydrogenation process. Addition of CG at 7.5, 15 and 22.5\% in feed lot lambs also had positive impact on odd-chain fatty acids (oleic, palmitoleic), total unsaturated and monounsaturated fatty acids which in turn increased the quality of the meat. Further increase in CG to $30 \%$ reduced the carcass weight and yield (Carvalho et al., 2015). In ruminants, digestion of fat involves the lipolysis and bio-hydrogenation in the rumen. Added glycerol interrupting the bio-hydrogenation results in increased concentration of conjugated linolenic acid (CLA) in meat (Lage et al., 2014a; Carvalho et al., 2015). CLA having added beneficial effect in human health helps in protection against cancer, diabetes and cardiovascular diseases (Schmid et al., 2006). Avila-Stagno et al. (2013)fed lambs with increasing CG concentration (7, 14 and $21 \%$ ) by replacing with barley and observed no effect on total saturated fatty acids or mono unsaturated fatty acids; however, poly unsaturated fatty acids were linearly decreased. Humectant property of glycerol makes it to absorb moisture from the surrounding; because of this property glycerol is more commonly used in food and beverage industry. Similarly, it is expected to increase the water holding capacity of meat which in turn increases the juiciness (Freund et al., 1995). Increase in muscle water content was reported by Parker et al. (2007) in steers, however, no such effect was reported in other studies (Eiras et al., 2014; Chanjula et al., 2014; Carvalho et al., 2015). Based on the several research studies EFSA (2010) has approved the use of CG in animal feeding without any deleterious effect up to $15 \%$ in ruminants and $10 \%$ in monogastric animals.

\section{Conclusion and future prospective}

Increased concern about environmental pollution and call for use of biodiesel is expected to increase the biodiesel production globally. Use of CG as an energy source by replacing grains in animal feeding can be a better alternative than disposal or purification. Nutrient composition of CG depends on the substrate and procedure involved in the biodiesel extraction. Methanol content of CG can be minimized up to the permeable limit by a simple process of evaporation. More than $10 \%$ of CG in mash type of diet decreases the feed quality in poultry and pig. Up to 15 $\%$ or even more than that also showed no negative impact on feed utilization and production in ruminants. Feeding CG did not affect the feed intake and nutrient digestibility except fibre, on which their effect is still uncertain. Carcass dressing percentage, bodyweight gain is not altered by CG feeding. Further studies are needed to assess their effect on meat fatty acid profile, CLA content and methanogenesis in ruminants.

\section{Conflict of interest}

Authors declare that there is no conflict of interest.

\section{Acknowledgments}

All the authors acknowledge the support from their respective institutions and universities.

\section{Reference}

Abo El-Nor S, AbuGhazaleha AA, Potua RB, Hastingsa D, Khattab MSA (2010) Effects of differing levels of glycerol on rumen fermentation and Bacteria. Animal Feed Science and Technology 62: 99-105.

Al-Zuhair S (2007) Production of biodiesel: possibilities and challenges. Biofuels, Bioproducts and Biorefining 1: 57-66.

Avila JS, Chavesa AV, Hernandez-Calva M, Beauchemin KA, McGinn SM, Wang Y, Harstad OM, McAllister TA (2011) Effects of replacing barley grain in feedlot diets with increasing levels of glycerol on in vitro fermentation and methane production. Animal Feed Science and Technology166-167: 265268.

Avila-Stagno J, Alexandre V, Chaves, Gabriel O, Ribeiro Jr, Emilio M, Ungerfeld McAllister TA (2014) Inclusion of glycerol in forage diets increases methane production in a rumen simulation technique system. British Journal of Nutrition 111: 829-835.

Avila-Stagno J, Chaves AV, He ML, Harstad OM, Beauchemin KA, McGinn SM, McAllister TA (2013) Effects of increasing concentrations of glycerol in concentrate diets on nutrient digestibility, methane emissions, growth, fatty acid profiles, and carcass traits of lambs. Journal of Animal Science 91: 829-837.

Barton L, Bures D, Homolka P, Jancik F, Marounek M, Rehak D (2013) Effects of long-term feeding of crude glycerine on performance, carcass traits, meat quality, and blood and rumen metabolites of finishing bulls. Livestock Science 155: 53-59.

Benedeti DB, Galoro da Silva P, Marostegan de Paula L, Shenkoru E, Marcondes T, Monteiro MI, Amorati HF, Yeh B, Poulson Y, Faciola SR (2015) Effects of Partial Replacement of Corn with Glycerin on Ruminal Fermentation in a Dual-Flow Continuous Culture System. PLoS One 10: e0143201.

Bernardino VMP, Rodrigues PB, Freias RTF, Gomide EM, Makiyama L, Bueno RS, Oliveira DH, Lara LJ (2015) Sources and levels of glycerin for broilers from 22 to 35 days. African Journal of Agricultural Research 10: 1259-1265. 
Carvalho PLO, Ivan M, Elias NM, Liliane MP, Juliana BT, Clodoaldo de Lima CF (2012b) Crude glycerine in diets for piglets. RevistaBrasileira de Zootecnia 41:1654-1661.

Carvalho VB, Leite RF, Almeida MTC, Paschoaloto JR, Carvalho EB, Lanna DPD, Perez HL, Van Cleef EHCB, Homem Junior AC, Ezequiel JMB (2015) Carcass characteristics and meat quality of lambs fed high concentrations of crude glycerin in lowstarch diets. Meat Science 110: 285-292.

Carvalho VB, Leite RF, Almeida MTC, Paschoaloto JR, Carvalho EB, Lanna DPD, Perez HL, Carvalho ERNS, SchmelzRoberts HM, White PH, Doane SS, Donkin (2012a) Replacing corn with glycerol in diets for transition dairy cows. Journal of Dairy Science 94:908-916.

Cerrate S, Yan F, Wang Z, Coto C, Sacakli P, Waldroup PW (2006) Evaluation of Glycerine from Biodiesel Production as a Feed Ingredient for Broilers. International Journal of Poultry Science 11:1001-1007.

Chanjula P, Pakdeechanuan P, Wattanasit S (2014) Effects of dietary crude glycerin supplementation on nutrient digestibility, ruminal fermentation, blood metabolites, and nitrogen balance of goats. Asian Australasian Journal of Animal Science 27: 365-374.

Chanjula P, Pongprayoon S, Kongpan S, Cherdthong A (2016b) Effects of crude glycerin from waste vegetable oil supplementation on feed intake, ruminal fermentation characteristics and nitrogen utilization of goats. Tropical Animal Health and Production 48: 995-1004.

Chanjula P, Raungprim T, Yimmongko S, Poonko S, Majarune S, Maitreejet W (2016a) Effects of Elevated Crude Glycerin Concentrations on Feedlot Performance and Carcass Characteristics in Finishing Steers. Asian Australasian Journal of Animal Science 29: 80-88.

DeFrain JM, Hippen AR, Kalscheur KF, Jardon PW (2004) Feeding glycerol to transition dairy cows: effects on blood metabolites and lactation performance. Journal of Dairy Science 87: 4195-4206.

Donkin SS (2008) Glycerol from biodiesel production: the new corn for dairy cattle. Revista Brasileira de Zootecnia 37: 280-286.

Dorman DC, Janice AD, Mark PN, Jethro E, Brad B, Michele AM (1993) Acute methanol toxicity in minipigs. Fundamental and Applied Toxicology 20:341-347.

Dozier WA, Kerr BJ, Corzo A, Kidd MT, Weber TE, Bregendahl K (2008) Apparent Metabolizable Energy of Glycerin for Broiler Chickens. Poultry Science 87: 317-322.

Edrisi SA, Dubey RK, Tripathi V, Bakshi M, Srivastava P, Jamil S, Singh HB, Singh N, Abhilash PC (2015) Jatropha curcas L.: A crucified plant waiting for resurgence. Renewable and Sustainable Energy Reviews 41: 855-862.
Edwards H, Anderson R, Miller R, Taylor T, Hardin M, Smith S, Krueger N, Nisbet D (2012) Glycerol inhibition of ruminal lipolysis in vitro. Journal of Dairy Science 95: 5176-5181.

EFSA (2010) Panel on Contaminants in the Food Chain (CONTAM) Scientific Opinion on the abiotic risks for public and animal health of glycerine as co-product from the biodiesel production from Category 1 animal by-products (ABP) and vegetable oils. EFSA 12: 1934-1945.

Egea M, Linares MB, Garrido MD, Madrid J, Hernández F (2016) Feeding Iberian $\times$ Duroc cross pigs with crude glycerine: Effects of diet and gender on carcass and meat quality. Meat science 111: 78-84.

Egea M, Linares MB, Garrido MD, Villodre C, Madrid J, Orengo J, Martínez S, Hernández F (2014) Crude glycerine inclusion in Limousin bull diets: Animal performance, carcass characteristics and meat quality. Meat science 98: 673-678.

Eiras CE, Marques JA, Prado RM, Valero MV, Bonafé EG, Zawadzki F, Perotto D, Prado IN (2014) Glycerin levels in the diets of crossbred bulls finished in feedlot: Carcass characteristics and meat quality. Meat science 96: 930-936.

Energy Statistics Report (2003) New Delhi: Central Statistical Organization. Ministry of Statistics and Programme Implementation, Government of India, New Delhi, India.

FDA (2010) US Food and Drug Administration (2010) Food additives permitted in feed and drinking water of animals. Methyl esters of higher fatty acids. Available at https://www.accessdata.fda.gov/scripts/cdrh/cfdocs/cfcfr/cfrsearch .cfm access on 25th April. 2017.

Fisher LJ, Erfle JD, Sauer FD (1971) Preliminary evaluation of the addition of glucogenicmaterials to the rations of lactating cows. Canadian Journal of Animal Science 25:721-727.

Francozo MC, Prado IN, Cecato U, Valero MV, Zawadzki F, Ribeiro OL, Prado RM, Visentainer JV (2013) Growth performance, carcass characteristics and meat quality of finishing bulls fed crude glycerine-supplemented diets. Brazilian Archives of Biology and Technology 56: 327-336.

Freund BJ, Montain SJ, Young AJ, Sawka MN, DeLuca JP, Pandolf KB, Valeri CR (1995) Glycerol hyperhydration: Hormonal, renal, and vascular fluid responses. Journal of Applied Physiology 79: 2069-2077.

Groesbeck CN, Mckinney LJ, Derouchey JM (2008) Effect of crude glycerol on pellet mill production and nursery pig growth performance. Journal of Animal Science 86: 2228-2236.

Hansen CF, Hernandez A, Mullan BP, Moore K, Trezona-Murray M, King RH, Pluske JR, (2009) A chemical analysis of samples of crude glycerol from the production of biodiesel in Australia, and the effects of feeding crude glycerol to growing-finishing pigs on performance, plasma metabolites and meat quality slaughter. Animal Production Science 49: 154-161. 
Hu SX, Luo C, Wan, Li Y (2012) Characterization of crude glycerol from biodiesel plants. Journal of Agricultural and Food Chemistry 60: 5915-5921.

IPCC (2014) Intergovernmental panel on climatic change https://www.ipcc.ch/pdf/assessmentreport/ar5/wg3/drafts/fgd/ipcc _wg3_ar5_summary-for-policymakers_approved.pdf access on 29th April, 2017.

Jung B, Batal AB (2011) Nutritional and feeding value of crude glycerine for poultry. 1. Nutritional value of crude glycerin. Journal of Applied Poultry Research 20: 162-167.

Kass M, Tiia A, Jaak S, Katri L, Hanno J, Tanel K, David A, Olav K, Meelis O (2013) Long-term oral drenching of crude glycerol to primiparous dairy cows in early lactation. Animal Feed Science and Technology 184: 58- 66.

Kass M, Tiia A, Tanel K, Rihma E, MeelisO, David A, Olav K (2012) Effect of replacement of barley meal with crude glycerol on lactation performance of primiparous dairy cows fed a grass silage-based diet. Livestock Science 150: 240-247.

Kijora C, Kupsch RD (1996) Evaluation of technical glycerol from biodiesel production as a feed component in fattening of pigs. European Journal of Lipid Science and Technology 98: 240 245.

Kim JH, Seongwon S, Chan HK, Jong WK, Byung BL, Gang IL, Hye SS, Moon CK, Dong YK (2013) Effect of dietary supplementation of crude glycerol or tallow on intestinal transit time and utilization of energy and nutrients in diets fed to broiler chickens. Livestock Science 54: 165-168.

Krehbiel CR (2008) Ruminal and physiological metabolism of glycerin. Journal of Animal Science 86: 392-395.

Lage JF, Berchielli TT, San VE, Silva RA, Ribeiro AF, Reis RA, Dallantonia EE, Simonetti LR, Delevatti LM, Machado M (2014a) Fatty acid profile, carcass and meat quality traits of young Nellore bulls fed crude glycerin replacing energy sources in the concentrate. Meat Science 96:1158-1164.

Lage JF, Paulino PVR, Pereira LGR, Duarte MS, Valadares Filho SC, Oliveira AS, Souza NKP, Lima JCM (2014b) Carcass characteristics of feedlot lambs fed crude glycerin contaminated with high concentrations of crude fat. Meat Science 96: 108-113.

Lammers PJ, Kerr BJ, Honeyman MS, Stalder K, Dozier WA, Weber TE, Kidd MT, Bregendahl. K (2008b) Nitrogen-Corrected Apparent Metabolizable Energy Value of crude glycerol for Laying Hens. Poultry Science 87:104-107.

Lammers PJ, Kerr BJ, Weber TE (2008a) Digestible and metabolizable energy of crude glycerol for growing pigs. Journal of Animal Science 86: 602-608.

Leng RA (1970) Glucose synthesis in ruminants. in Brandly CA, Cornelius CE (Eds.) Advances in Veterinary Science and Comparative Medicine. Vol. 14. Academic Press, New York. Pp 241-242.
Lokesha E, Dhinesh KR, Srinivas B (2017) Effect of feed additives on in vitro fermentation kineticsand substrate utilization with and without buffer. Applied Biological Research 1: 56-62.

Long CJ, Sneed AD, Schroeder AR, Felix TL (2015) Effects of dietary glycerin on growth performance, carcass characteristics, and rumen metabolism of beef cattle. The Professional Animal Scientist 31:568-576.

McDonald P, Edwards RA, Greenhalgh JFD, Morgan CA, Sinclair LA, Wilkinson RG (2010) Animal Nutrition (7th edn) pp 207.Pearson education, Ltd. Available on http://gohardanehco.com/wpcontent/uploads/2014/02/AnimalNutrition.pdf access on 25th April, 2017.

Min YN, Liu FZ, Wang Z, Coto C, Cerrate S, Costa FP, Yan F, Waldroup PW (2008) Evaluation of distillers dried grains with solubles in combination with glycerin in broiler diets. International Journal of Poultry 7: 646-654.

NASA (2015) National Aeronautics and Space Administration. Goddard Institute for Space Studies available http://earthobservatory.nasa.gov/Features/WorldOfChange/decada ltemp.php access on 25th April, 2017.

National Biofuel Policy (2015) Ministry of New and Renewable Energy National Policy on Biofuels New Delhi. Available on www.teriin.org/policybrief/docs/biofuel.pdf access on 29th April, 2017.

NRC (2001) Nutrient Requirements of Dairy Cattle. $7^{\text {th }}$ ed. National Academy of Science, Washington, DC, USA.

OECD/FAO (2015) "OECD-FAO Agricultural Outlook", OECD Agriculture statistics (database) available on http://dx.doi.org/10.1787/agr-outl-data-en access on 29th April, 2017.

Oliveira LJM, Ramis G, Martínez S, Orengo J, Villodre C, Valera L, López MJ, Pallarés FJ, Quereda JJ, Mendonça L, Hernández F(2014) Adding crude Adding crude glycerin to nursery pig diet: Effect on nutrient digestibility, metabolic status, intestinal morphology and intestinal cytokine expression. Livestock Science167: 227-235.

Omazic AW, Traven M, Bertilsson V, Holtenius K (2013) High and low-purity glycerine supplementation to dairy cows in early lactation: effects on silage intake, milk production and metabolism. Animal 9: 1479-1485.

Orengo J, Villodre C, Madrid J, Martínez S, López MJ, Megías MD, Valera L, Hernández F (2014) Effect of dietary crude glycerin on growth performance, nutrient digestibility and hormone levels of Iberian crossbred pigs from 50 to $100 \mathrm{~kg}$ body weight. Livestock Science 165: 95-99.

Paggi RA, Fayb JP, Fernandez HM (1999) Effect of short-chain acids and glycerol on the proteolytic activity of rumen fluid. Animal Feed Science and Technology78: 341-347. 
Papadomichelakis G, Pappas AC, Zoidis E, Mountzouris KC, Fegeros K (2015) Impact of feeding increasing crude glycerine levels on growth performance, glycerine kinase gene expression, nutrient digestibility and litter quality in broiler chickens. Livestock Science 181: 89-95.

Papadomichelakis G, Zoidis E, Mountzouris KC, Lippas T, Fegeros K (2012) Glycerine kinase gene expression, nutrient digestibility and gut microbiota composition in post-weaned pigs fed diets with increasing crude glycerine levels. Animal Feed Science and Technology 177: 247-252.

Parker AJ, Dobson GP, Fitzpatrick LA (2007) Physiological and metabolic effectsof prophylactic treatment with the osmolytes glycerol and betaine on Bosindicus steers during long duration transportation. Journal of Animal Science 85: 2916-2923.

Paschoaloto JR, Jane MBE, Marco TCA, Vanessa RF, Antonio CHJ, Vanessa BC, Henrique LP. (2016) Inclusion of crude glycerin with different roughages changes ruminal parameters and in vitro gas production from beef cattle. Cienc Rural Santa Maria 46: 889-894.

Patterson JA, Hespell RB (1979) Trimethylamine and methylamine as growth substrates for rumen bacteria and Methanosarcinabarkeri. Current Microbiology 3:79-83.

Patterson JA, Ricke SC (2015) Effect of ethanol and methanol on growth of ruminal bacteria Selenomonas ruminantium and Butyrivibrio fibrisolvens. Journal of Environmental Science and Health 50: 62-67.

Posada JA, Luis E, Rincón, Carlos A, Cardona (2012) Design and analysis of biorefineries based on raw glycerol: Addressing the glycerol problem. Bioresource Technology 111:282-293.

Refaat AA (2010) Different techniques for the production of biodiesel from waste vegetable oil. International Journal of Environmental Science and Technology 7: 183-213.

REN21 (2015) Renewable Energy Policy Network for the $21^{\text {st }}$ Century. Renewables 2015 Global status report.

San VE, Juliana D, Messana, Pablo S, Castagnino, Yury T, Granja-Salcedo, Erick E, Dallantonia, Telma T, Berchielli (2016) Effect of crude glycerine in supplementation the intake, rumen fermentation, and microbial profile of Nellore steers grazing tropical grass. Livestock Science 192: 17-24.

San VE, Lage JF, Ribeiro AF, Silva RA, Berchielli TT (2015) Fatty acid profile, carcass and quality traits of meat from Nellore young bulls on pasture supplemented with crude glycerin. Meat Science 100:17-23.
Schmid A, Collomb M, Sieber R, Bee G (2006) Conjugated linoleic acid in meat and meat products: A review. Meat Science 73: $29-41$.

Serrano RDC, Antonio FB, Silvana T, Milene O (2014) Evaluation of crude glycerine inclusion in beef cattle diet: apparent nutrient digestibility and microbial protein synthesis. Zootecnia Tropical 32:109-117.

Shin JH, Wang D, Kim SC, Adesogan AT, Staples CR (2012) Effects of feeding crude glycerin on performance and ruminal kinetics of lactating Holstein cows fed corn silage or cottonseed hull-based, low-fiber diets. Journal of Dairy Science 95: 40064016.

Shuit SH, Lee KT, Kamaruddin AH, Yusup S (2010) Reactive extraction and in situ esterification of Jatropha curcas L. seeds for the production of biodiesel. Fuel 89: 527-530.

Silveira H, Leticia MR, Leticia GMA, Luis GSC, Renato P, de Souza VC (2015) Digestible and metabolizable energy of crude glycerin for finishing Pigs. Acta Scientiarum. Animal Sciences 37: 41-45.

Singh B, Singh K, Rao GR, Chikara J, Kumar D, Mishra DK, Saikia SP, Pathre UV, Raghuvanshi N, Rahi TS, Tuli R (2013) Agro-technology of Jatropha curcas for diverse environmental conditions in India. Biomass and Bioenergy 48: 191-202.

Thompson JC, He BB (2006) Characterization of crude glycerol from biodiesel production from multiple feed stocks. Applied Engineering in Agriculture 22: 261-265.

USDA(2015) India Biofuels Annual 2015 Global Agricultural Information Network (GAIN) Report Number IN-5079, United States Department of Agriculture (USDA) Foreign Agricultural Service, New Delhi.

Van CEHCB, Almeida MTC, Perez HL, Van Cleef FOS, Silva DAV, Ezequiel JMB (2015) Crude glycerin changes ruminal parameters, in vitro greenhouse gas profile, and bacterial fractions of beef cattle. Livestock Science 178:158-164.

Wang C, Liu Q, Huo WJ, Yang WZ, Dong KH, Huang YX, Guo G, Wang Q, Liu, Huo WJ, Yang WZ, Dong KH, Huang YX, Guo G (2009) Effects of glycerol on rumen fermentation, urinary excretion of purine derivatives and feed digestibility in steers. Livestock Science 121: 15-20.

Yang F, Milford AH, Runcang S (2012) Value-added uses for crude glycerol $-\mathrm{a}$ byproduct of biodiesel production. Biotechnology for Biofuels 5:13. 